\title{
Helicobacter pylori infection as a risk factor for diabetes: a meta-analysis of case-control studies
}

Kamyar Mansori ${ }^{1}$, Yousef Moradi ${ }^{*}$, Sara Naderpour ${ }^{2}$, Roya Rashti ${ }^{3}$, Ali Baradaran Moghaddam ${ }^{4}$, Lotfolah Saed ${ }^{5}$ and Hedyeh Mohammadi ${ }^{6}$

\begin{abstract}
Background: There are several studies with varied and mixed results about the possible relationship between $H$. pylori and diabetes. Therefore, this current meta-analysis performed to determine the association between $\mathrm{H}$. pylori infection and the risk of diabetes mellitus.

Methods: A systematic literature searches of international databases, including Medline (PubMed), Web of Sciences, Scopus, EMBASE, and CINHAL (January 1990-March 2019) was conducted to identify studies investigating the relationship between $\mathrm{H}$. pylori infection and diabetes mellitus. Only case-control studies were analyzed using odds ratio (OR) with 95\% confidence intervals (Cls). Stratified and subgroup analyses were performed to explore heterogeneity between studies and assess effects of study quality. Logarithm and standard error logarithm odds ratio (OR) were also used for meta-analysis.

Results: A total of 41 studies involving 9559 individuals (case; 4327 and control; 5232) were analyzed. The pooled estimate of the association between $H$. pylori infection with diabetes was $\mathrm{OR}=1.27$ (95\% Cl 1.11 to $1.45, P=0.0001$, $\mathrm{I}^{2}=86.6 \%$ ). The effect of $\mathrm{H}$. pylori infection on diabetes mellitus (both types), type 1 and type 2 diabetes was 1.17 ( $95 \% \mathrm{Cl} 0.94$ to 1.45$), 1.19$ (95\% Cl 0.98 to 1.45 ), and 1.43 (95\% Cl 1.11 to 1.85 ) respectively. Subgroup analysis by the geographical regions showed in Asian population risk of the effect of $\mathrm{H}$. pylori infection on diabetes was slightly higher than other population,
\end{abstract}

Conclusion: In overall a positive association between H. pylori infection and diabetes mellitus was found.

Keywords: Helicobacter pylori, Diabetes mellitus, Type 1 diabetes, Type 2 diabetes, Meta-analysis

\section{Background}

Helicobacter pylori (H. pylori) is a gram-negative spiral bacterium which is found abundantly in the stomach. The H. pylori infection is one of the most common chronic infections in the world, so that more than $50 \%$ of the world's population are infected with this infection $[1,2]$. It is now known that H. pylori is responsible for

\footnotetext{
* Correspondence: yousefmoradi211@yahoo.com

${ }^{2}$ Department of Epidemiology, School of Public Health, Iran University of Medical Sciences, Tehran, Iran

Full list of author information is available at the end of the article
}

most cases of peptic ulcer disease. Also, the different studies highlighted that it is associated with other important gastrointestinal diseases such as chronic gastritis, gastric adenocarcinoma, and MALT lymphoma which are recognized as a major public health concern in the world [3, 4]. In addition to the role of $H$. pylori in gastrointestinal disorders, some researches have suggested the potential role of this bacterium in the development of non-gastrointestinal disorders such as cardiovascular diseases and metabolic syndrome especially diabetes [5-7]. Diabetes is the most common

C C The Author(s). 2020 Open Access This article is licensed under a Creative Commons Attribution 4.0 International License, which permits use, sharing, adaptation, distribution and reproduction in any medium or format, as long as you give appropriate credit to the original author(s) and the source, provide a link to the Creative Commons licence, and indicate if changes were made. The images or other third party material in this article are included in the article's Creative Commons licence, unless indicated otherwise in a credit line to the material. If material is not included in the article's Creative Commons licence and your intended use is not permitted by statutory regulation or exceeds the permitted use, you will need to obtain permission directly from the copyright holder. To view a copy of this licence, visit http://creativecommons.org/licenses/by/4.0/ The Creative Commons Public Domain Dedication waiver (http://creativecommons.org/publicdomain/zero/1.0/) applies to the data made available in this article, unless otherwise stated in a credit line to the data. 
metabolic disease in the world and responsible for about 4 million deaths per year. The global prevalence of diabetes was $4.6 \%$ equivalent to 285 million in adults for 2010 , which this number has reached 371 million in 2012, and is expected to reach 552 million by 2030 [8-10].

As mentioned above, one of the factors that may affect incidence of diabetes is $H$. pylori. The relationship between $H$. pylori infection and diabetes was introduced in 1989 [11]. It has been suggested that the H. pylori may be contributed to the incidence of cardiovascular disease and diabetes through elevations in inflammatory cytokines levels such as C-reactive protein (CRP) and interleukin-6 [11-13]. In general, various studies have investigated the role of $H$. pylori in the pathogenesis of diabetes and its complications, but the results are inconsistent with each other. For example, some case-control studies have reported higher prevalence of $H$. pylori in patients with diabetes [14, 15]. Also, several crosssectional studies have shown a significant statistical association between $H$. pylori and diabetes [3, 15]. However, some studies in this regard have shown that there is no significant association between diabetes and prevalence H. pylori infection $[2,16,17]$.

Therefore, the association between $H$. pylori infection and the risk of diabetes is still controversies. Hence, this systematic review and meta-analysis study was designed to identify the possible association between $H$. pylori infection and the risk of diabetes.

\section{Methods}

This systematic review and Meta-analysis was performed according to the Preferred Reporting Items for Systematic Reviews and Meta-analyses (PRISMA) and Strengthening the Reporting of Observationally Studies in Epidemiology (STROBE) guidelines for reviews of analytical observational studies (case-control) [18-20].

\section{Search terms and complex search syntax}

All original published articles were searched from January 1990 to March 2019 without language limitations in international databases, including Medline (PubMed), Web of Sciences, Scopus, EMBASE, Cochrane, Ovid and CINHAL. The keywords were Diabetes, Diabetes Mellitus (type 1 and 2), Insulin Dependent, IDDM, NIDDM, Noninsulin Dependent, Insulin Sensitivity, Helicobacter pylori, Campylobacter pylori, and $\mathrm{H}$ Pylori. Two reviewers (YM and $R R$ ) abstracted data independently and reached consensus on all items. Inclusion and exclusion criteria were set by two researchers separately (YM and RR) (Fig. 1).

\section{Eligibility criteria}

A published study had to meet the following inclusion criteria:
(1) case-control, nested case control studies, (2) human population, and (3) Helicobacter pylori infection was exposure variable. Case reports, reviews, animal studies, and cohort studies were removed from the tabulation. The authors resolved all disputes during the collection, compilation, and analysis of data.

\section{Data extraction}

Two reviewers ( $\mathrm{YM}$ and $\mathrm{RR}$ ) independently extracted the data. A structured checklist was used for the extraction of information including; 1) name of first author, 2) date of publication, 3) country, 4) study subjects, 5) age of patients, 6) sample size, 7) type of diabetes, 8) mean of $\mathrm{HbA1C}, 9)$ duration of diabetes, 10) measurement of association, 11) controlled variables, 12) and method of bacteria detection. In addition, type of instruments (detection of $H$. pylori) was extracted from each study in case of reporting. A data extraction form was created based on our group discussion and piloted according to 10 different types of studies. Then, it was modified and used by the data extractor. All process from systematic search to final data extraction were followed independently by two research experts (Kappa statistic for agreement for quality assessment; 0.75). Any disagreement was assessed by both and if a consensus was not reached, a third author (LS) evaluate the study. The qualities of all studies were assessed by Modified Newcastle-Ottawa Scale for Case Control studies [21].

\section{Statistical analysis}

Logarithm and standard error logarithm odds ratio (OR) were used for the meta-analysis. DerSimonian and Laird method was used to compute the pooled estimate of odds ratio (OR) with confidence interval (CI 95\%) using random models [22]. Because the test for heterogeneity was statistically significant in some analyses, the random effects models were used to estimate OR. In this study, w Cochran's Q test and I2 statistic were used to evaluate statistical heterogeneity between studies [23]. In addition, a meta-regression and subgroup analysis were performed to assess the source of heterogeneity between studies. Moreover, publication bias was assessed by funnel plot and Egger test [24, 25]. Statistical analysis was performed using STATA 14.0 (Stata Corp, College Station, TX, USA), and statistical significance was set at $p<0.05$.

\section{Results}

\section{Study characteristics}

The first step of search in electronic databases yielded 2027 publications and 200 studies identified through other sources. In the final step, after removing the duplicates, reviewing by title, abstract and full text and considering the inclusion and exclusion criteria, 41 studies were selected for the meta-analysis of pooled association between $H$. 


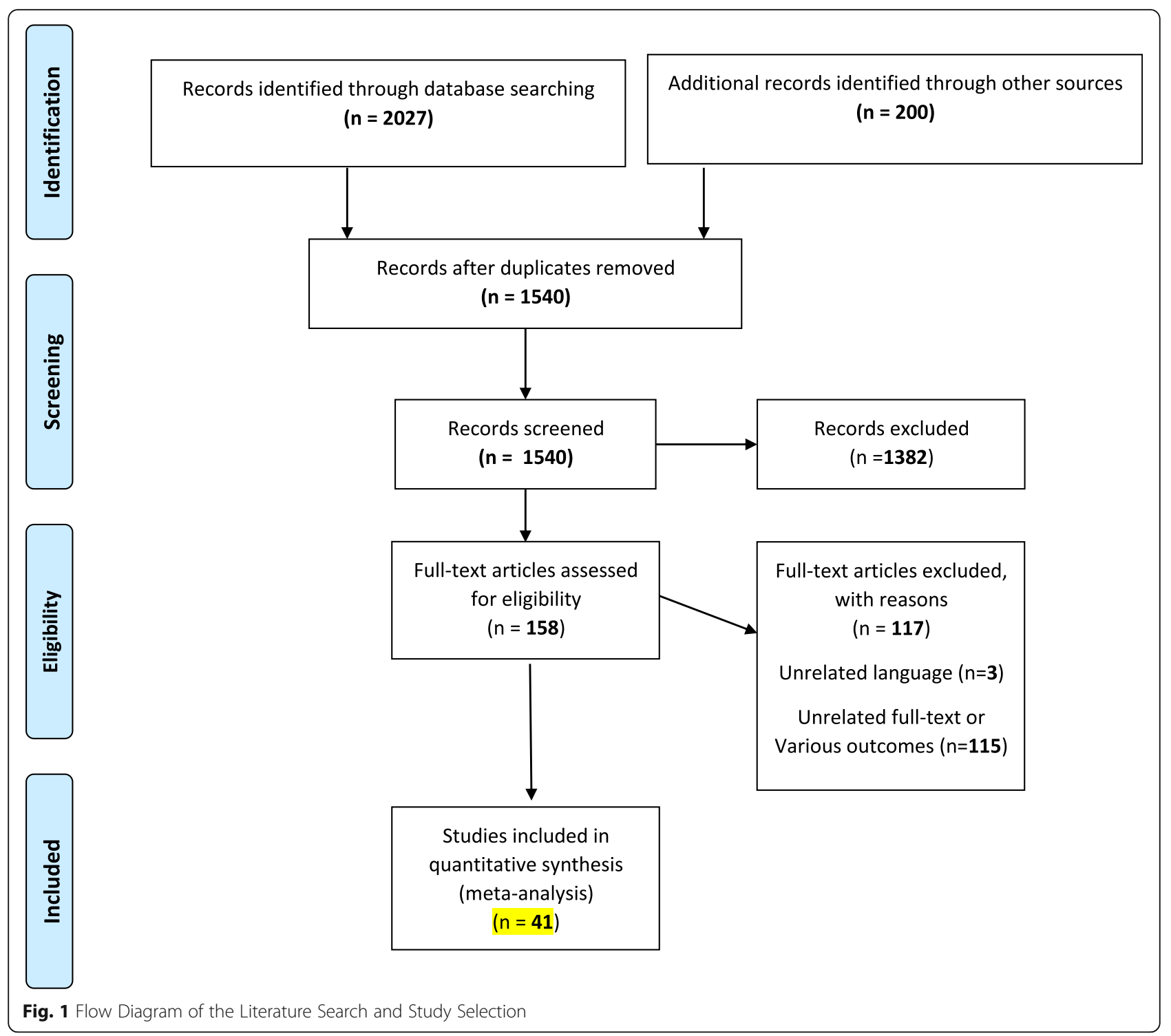

pylori infection and the risk of diabetes (Fig. 1). Characteristics of included studies in this meta-analysis are reported in Table 1 . The total sample size in the 41 studies that reported the association between $H$. pylori infection and the risk of diabetes in case and control was 4327 and 5232, respectively. Also, 11 studies reported association between $H$. pylori infection with DM. Other primary studies reported association between $H$. pylori infection with type 1 and 2 diabetes. A total of 41 studies were included in this metaanalysis, of which 20 were conduct in European, 12 were in Asian, 7 studies done in African and 2 in American (Table 2). Of the 41 studies, 18 showed statistically significant between $H$. pylori infection and the risk of diabetes.

The pooled estimate of the association between $\mathrm{H}$. pylori infection with diabetes mellitus was 1.27 (95\% CI 1.11 to $1.45, P=0.0001, \mathrm{I}^{2}=86.6 \%$ ) (Fig. 2 ), but since the $\mathrm{CI}$ of test (Egger's test) included zero, no significant bias occurred in the publication of the results (Egger's test $=$ 1.579, $P=0.073,95 \% \mathrm{CI}-0.154$ to 3.312 ) (Fig. 3).

\section{Subgroup analysis}

Based on the random effect model, the effect of $H$. pylori infection on diabetes mellitus, type 1 and type 2 diabetes was 1.17 (95\% CI 0.94 to 1.45 ), 1.19 (95\% CI 0.98 to 1.45), and 1.43 (95\% CI 1.11 to 1.85) respectively. Effect size of $H$. pylori infection on type 2 diabetes was higher than type 1 and diabetes mellitus (Table 2). Some of the primary studies did not mention that the study population was type 1 or type 2 , therefore we decided to include these types of studies as diabetes mellitus group in subgroup analysis.

Subgroup analysis by the geographical regions showed in Asian population risk of the effect of $H$. pylori infection on diabetes was higher than other population. In 


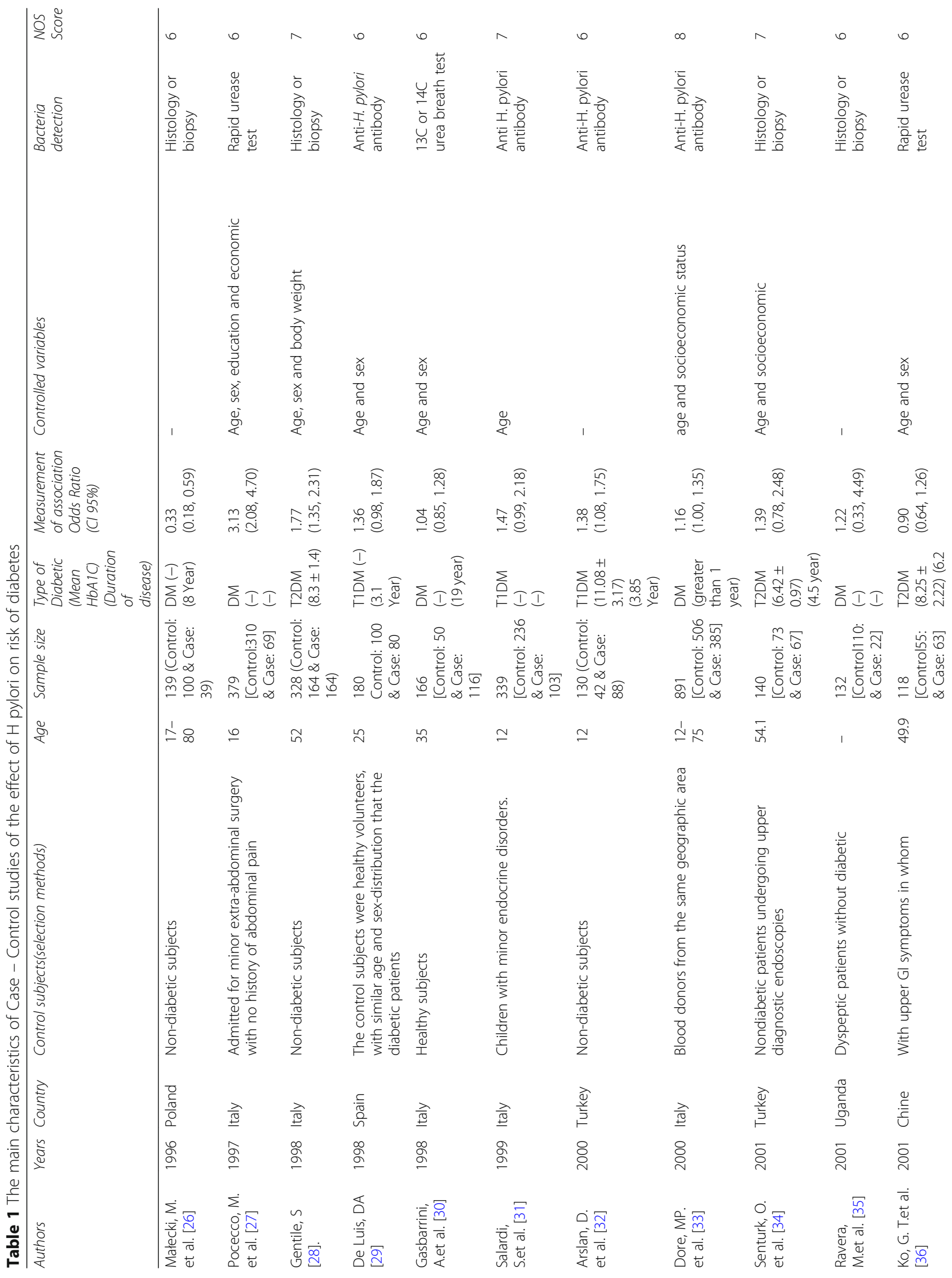




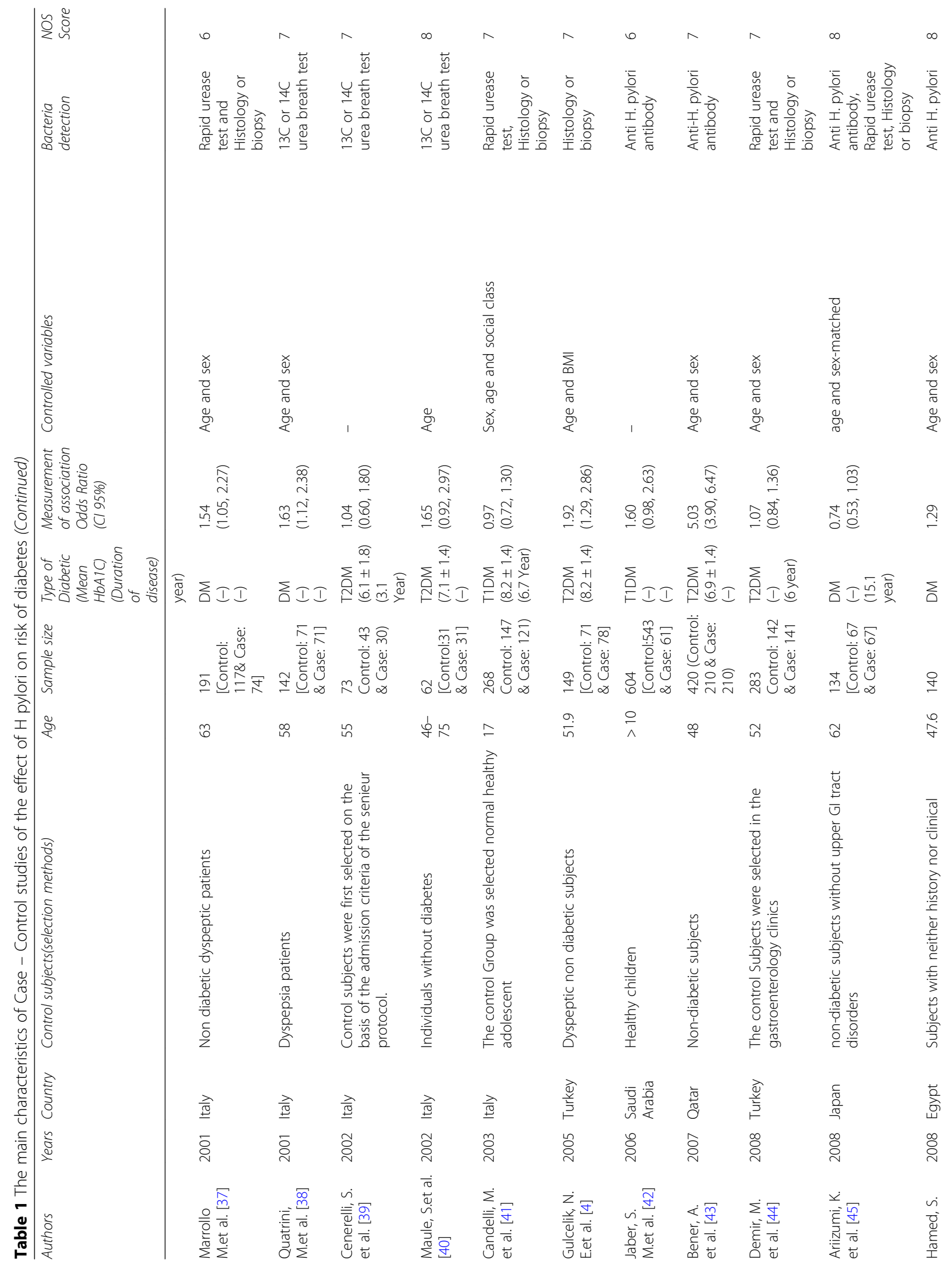




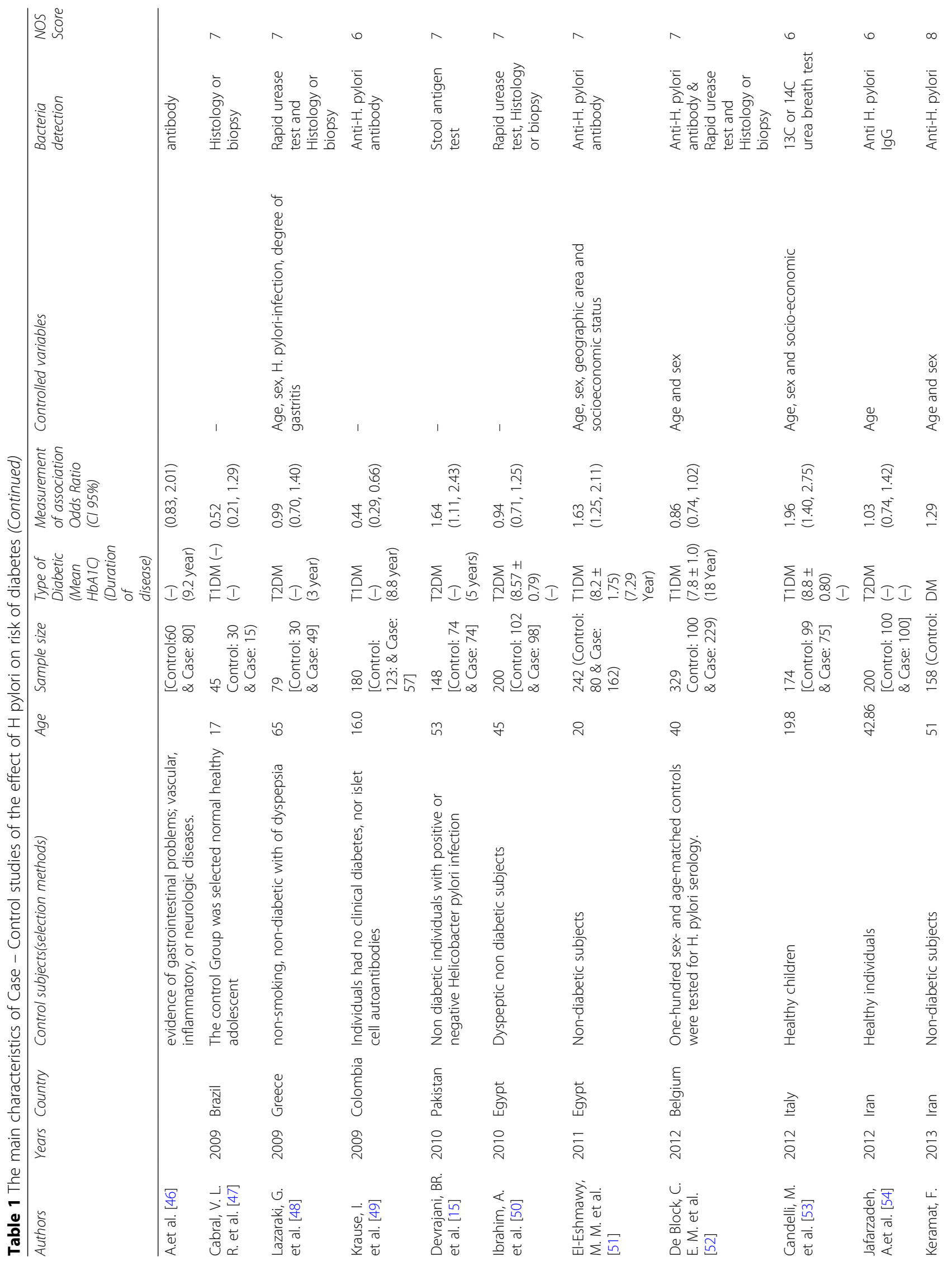




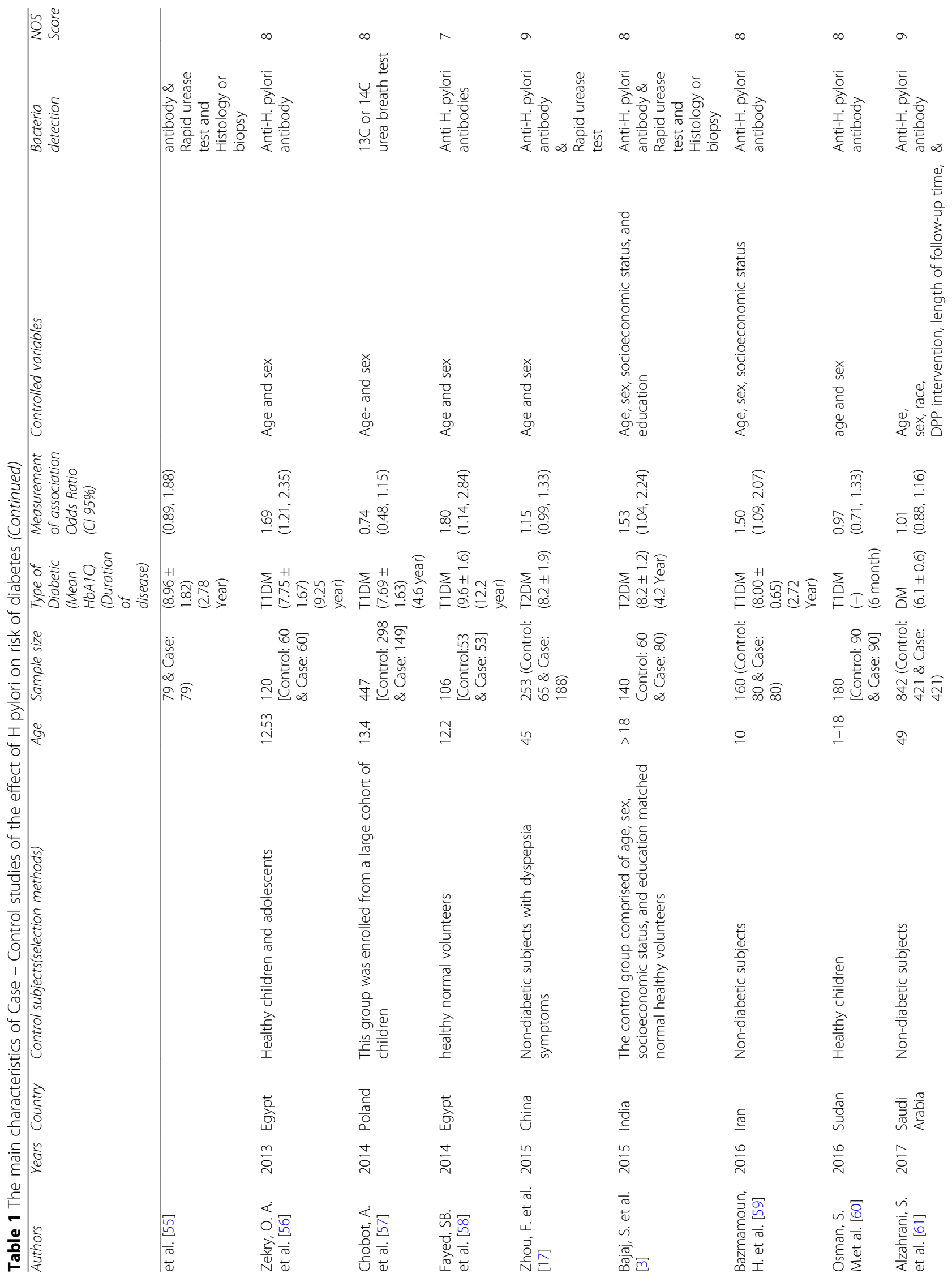




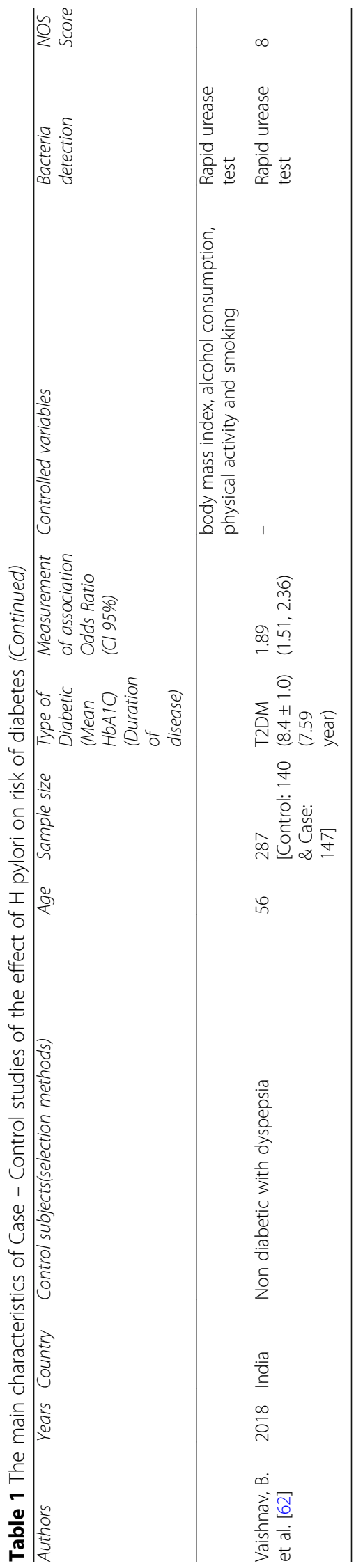




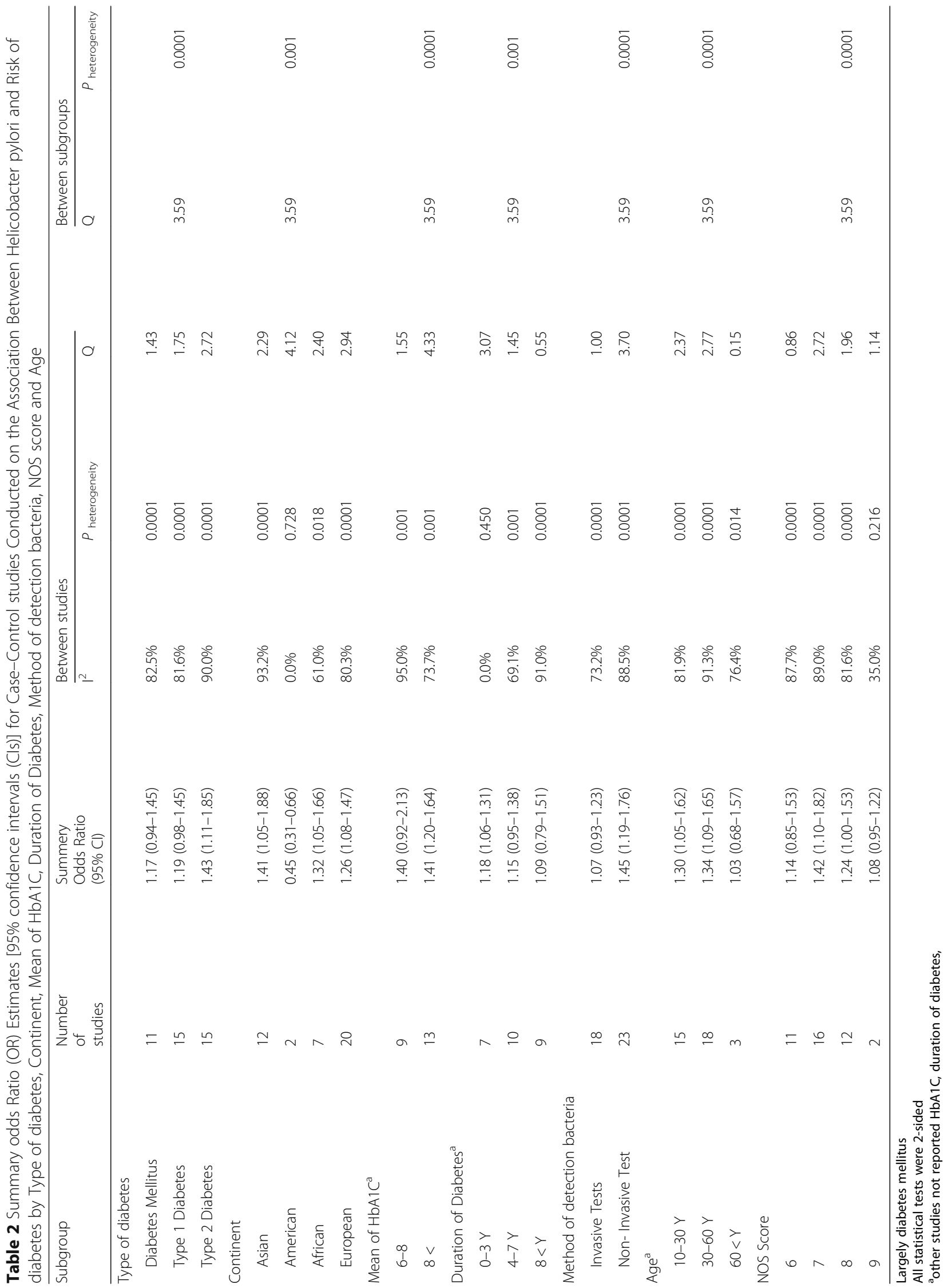




\begin{tabular}{|c|c|c|c|}
\hline $\begin{array}{l}\text { Study } \\
\text { ID }\end{array}$ & & $\begin{array}{l}\text { Odds } \\
\text { Ratio ( } 95 \% \mathrm{cl} \text { ) }\end{array}$ & $\begin{array}{l}\% \\
\text { Weight }\end{array}$ \\
\hline Makecki, M. et al (1996) & 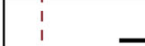 & $0.33(0.18,0.59)$ & $\begin{array}{l}1.88 \\
2.38\end{array}$ \\
\hline $\begin{array}{l}\text { Pocecoo, M. et al (1997) } \\
\text { Gentile, S. et al (1998) }\end{array}$ & $\longrightarrow$ & $\begin{array}{l}3.13(2.08,4.70) \\
1.77(1.35,2.31)\end{array}$ & $\begin{array}{l}2.36 \\
2.72\end{array}$ \\
\hline $\begin{array}{l}\text { Gentle, S. et al (1998) } \\
\text { De Luis, D. A. et al (1998) }\end{array}$ & & $1.36(0.98,1.87)$ & 2.59 \\
\hline Gasbarrini, A. et al (1998) & & $1.04(0.85,1.28)$ & 2.86 \\
\hline Salardi, S.et al (1999) & & $1.47(0.99,2.18)$ & 2.40 \\
\hline Arslan, D. et al (2000) & $\frac{1}{1+}$ & $1.38(1.08,1.75)$ & 2.78 \\
\hline Dore, MP. et al (2000) & + & $1.16(1.00,1.35)$ & 2.96 \\
\hline Senturk, $O$. et al (2001) & & $1.39(0.78,2.48)$ & 1.91 \\
\hline Ravera, M.et al (2001) & & $1.22(0.33,4.49)$ & 0.75 \\
\hline Ko, G. T.et al (2001) & 一 & $0.90(0.84,1.28)$ & 2.55 \\
\hline Marrollo M. et al (2001) & & $1.54(1.05,2.27)$ & 2.43 \\
\hline Quatrini, M.et al (2001) & & $1.63(1.12,2.38)$ & 2.45 \\
\hline Cenerelli, S. et al (2002) & & $1.04(0.80,1.80)$ & 1.98 \\
\hline Maule, S.et al (2002) & & $1.65(0.92,2.97)$ & 1.89 \\
\hline Candelli, M. et al (2003) & - & $0.97(0.72,1.30)$ & 2.68 \\
\hline Gulcelik, N. E.et al (2005) & & $1.92(1.29,2.86)$ & 2.39 \\
\hline Jaber, S. M.et al (2006) & & $1.60(0.98,2.63)$ & 2.13 \\
\hline Bener, A. et al (2007) & & $5.03(3.90,6.47)$ & 2.76 \\
\hline Demir, M. et al (2008) & & $1.07(0.84,1.36)$ & 2.78 \\
\hline Arizumi, K. et al (2008) & & $0.74(0.53,1.03)$ & 2.56 \\
\hline Hamed, S. A.et al (2008) & & $1.29(0.83,2.01)$ & 2.27 \\
\hline Cabral, V. L. R. et al (2009) & & $0.52(0.21,1.29)$ & 1.24 \\
\hline Lazaraki, G. et al (2009) & 1 & $0.99(0.70,1.40)$ & 2.52 \\
\hline Krause, I. et al (2009) & & $0.44(0.29,0.68)$ & 2.34 \\
\hline Devrajani, BR. et al (2010) & & $1.64(1.11,2.43)$ & 2.41 \\
\hline Ibrahim, A. et al $(2010)$ & & $0.94(0.71,1.25)$ & 2.69 \\
\hline El-Eshmawy, MM. et al (2011) & & $1.63(1.25,2.11)$ & 2.74 \\
\hline De Block, C. E. M. et al (2012) & & $0.88(0.74,1.02)$ & 2.94 \\
\hline Candelli, M. et al (2012) & & $1.96(1.40,2.75)$ & 2.55 \\
\hline Jafarzadeh, A.et al (2012) & & $1.03(0.74,1.42)$ & 2.58 \\
\hline Keramat, $F$. et al $(2013)$ & & $1.29(0.89,1.88)$ & 2.45 \\
\hline Zekry, O. A. et al $(2013)$ & & $1.69(1.21,2.35)$ & 2.57 \\
\hline Chobot, A. et al (2014) & - & $0.74(0.48,1.15)$ & 2.30 \\
\hline Fayed, SB. et al (2014) & & $1.80(1.14,2.84)$ & 2.23 \\
\hline Zhou, F. et al $(2015)$ & 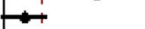 & $1.15(0.99,1.33)$ & 2.96 \\
\hline Bajaj, S. et al (2015) & & $1.53(1.04,2.24)$ & 2.43 \\
\hline Bazmamoun, H. et al (2016) & $\frac{1}{1}$ & $1.50(1.09,2.07)$ & 2.59 \\
\hline Osman, S. M.et al (2016) & - & $0.97(0.71,1.33)$ & 2.62 \\
\hline Alzahrani, S. et al (2017) & & $1.01(0.88,1.16)$ & 2.97 \\
\hline Vaishnav, B. et al (2018) & $1-$ & $1.89(1.51,2.36)$ & 2.82 \\
\hline Overall (I-squared $=86.8 \%, p=0.000$ ) & $\infty$ & $1.27(1.11,1.45)$ & 100.00 \\
\hline & \multirow{2}{*}{\multicolumn{3}{|c|}{6.47}} \\
\hline .154 & & & \\
\hline
\end{tabular}

Fig. 2 Association between Helicobacter pylori and Risk of diabetes (DM, T2DM and T1DM)

Funnel plot with pseudo $95 \%$ confidence limits

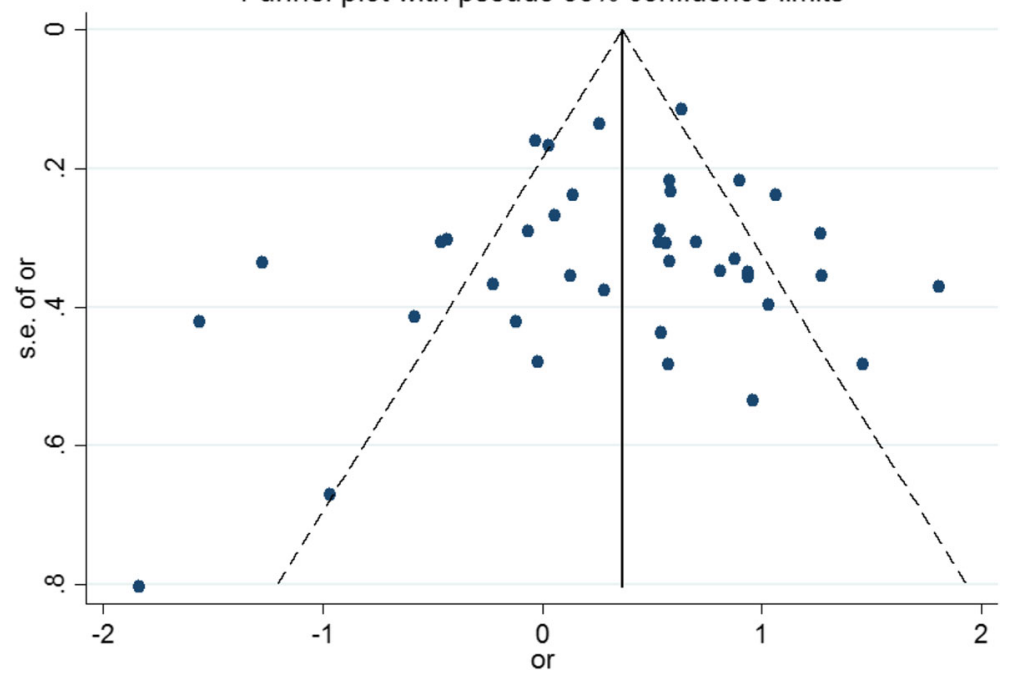

Fig. 3 Funnel plot of association between Helicobacter pylori and Risk of diabetes 
addition, the relationship between $H$. pylori and the risk of diabetes according to age showed that risk in individual with 30 to 60 years was 1.34 (95\% CI 1.09, 1.65), in 10 to 30 years, and upper 60 years was 1.34 (95\% CI $1.05,1.62)$ and $1.03(95 \%$ CI $0.93,3.23)$, respectively (Table 2).

The effect of $H$. pylori infection on diabetes mellitus by non- invasive testes detected was higher than invasive tests methods, (Table 2).

\section{Discussion}

Our systematic review and meta-analysis suggest that there is a positive association between $H$. pylori infection and diabetes. The results showed a significant statistical association between $H$. pylori infection and the risk of diabetes (overall OR: 1.27; 95\% CI: 1.11-1.45). The results of subgroup analysis by type of diabetes revealed a significant association between $H$. pylori infection and the risk of type 2 diabetes (OR: 1.43; 95\% CI: 1.11-1.85). However, this meta-analysis showed a positive relationship between $H$. pylori and the risk of type 1 diabetes (OR: 1.19; 95\% CI: 0.98-1.45) and diabetes mellitus (OR: 1.17; $95 \%$ CI: 0.94-1.45) but statistically were not significant. Subgroup analysis by the geographical regions showed a significant direct relationship between $H$. pylori and the risk of diabetes in Asian, Europe and Africa but in the American population this association was negative. In addition, in subgroup analysis, the relationship between $H$. pylori and the risk of diabetes was different based to age, level of $\mathrm{HbA1C}$, duration of diabetes and methods for $H$. pylori detection. This suggests that these factors could be an important source of heterogeneity in the studies included in the meta-analysis.

Our meta-analysis suggests that $H$. pylori infection may increase the risk of diabetes by up to $27 \%$. These findings are consistent with the results of several metaanalysis studies that have been done in this field. According to our knowledge, three other meta-analysis studies have been conducted regarding the association between $H$. pylori and diabetes. The first study which has been conducted by Jun-Zhen Li on 79 studies with 57,397 individuals from January 1996 to January 2016, showed that the prevalence of $H$. pylori infection in diabetes mellitus patients was significantly higher than nondiabetic (OR: 1.69; 95\% CI: 1.47-1.95), however, this difference was only significant for type 2 diabetes (OR: 2.05; 95\% CI: 1.67-2.52) [2]. The second study that was carried out by FENG WANG on 39 eligible studies for meta-analysis form 1997 and 2012, revealed that the $H$. pylori infection also associated with increased risks of type 1 (OR: $1.99,95 \%$ CI 1.52-2.60) and type 2 diabetes (OR: 2.15, 95\% CI 1.81-2.55) [63]. In the third metaanalysis study by Zhou et al. on 41 articles and 14,080 participants, the results reveled a significant association between $H$. pylori infection and increased risks of diabetes (OR: 1.33; 95\% CI: 1.08-1.64) [64]. However, some studies did support significant association between $H$. pylori infection and the risk of diabetes $[16,65]$.

Several mechanisms have been proposed for the relationship between $H$. pylori infection and risk of diabetes. Inflammatory cytokine may lead to induce phosphorylation of serine residues on the insulin receptor substrate and subsequently this phenomenon may impair the interaction between the substrate and the insulin receptors due to impaired insulin function [7, 66]. Also, Lipopolysaccharides from gram-negative bacteria such as $H$. pylori may activate Toll-like receptors and subsequently insulin resistance occurs [67]. All of these events can lead to reduced blood sugar control and consequently diabetes mellitus. In addition, the presence of bacterial infections can lead to microvascular failure and eventually incidence of atherosclerosis [68].

In subgroup analysis of geographical regions by the type of continent, we explored a significant direct relationship between $H$. pylori and the risk of diabetes in Asian, Europe and Africa but not in the American, however there was still high heterogeneity within these subgroups, therefore the interpretation of this negative result would be difficult. This was consistent with study of Jun-Zhen Li et al. that have shown H. pylori infection is significantly higher in patients with diabetes residing in Asia and Europe than in Africa and the American [69]. Also, Wang F et al. reported H. pylori can increase the risk of diabetes in European, Middle East and South Asia [63]. But, study carried out by Zhou et al. found $H$. pylori infection is significantly higher in patients with diabetes residing in only Asia [64]. This difference in various continents may be due to differences in sample size, different diagnostic methods and different medical care conditions. However, to determine the precise effect of geographical location on the association between $H$. pylori and diabetes risk, it is suggested to carry out further studies to look at the role of genetic and environmental factors particularly in migrant populations.

Also, in subgroup analysis, we found a significant direct relationship between $H$. pylori and the risk of diabetes in mean of $\mathrm{HbA1C}>8$. This result was in line with the results of other studies in this field. For example, the study by Ming-Chia Hsieh et al. revealed that there is a significant and direct statistical relationship between prevalence of $H$. pylori and serum HbA1c levels but not fasting glucose levels after adjusting for sex, age, BMI and family history of diabetes mellitus, so that the positive $H$. pylori group had significantly higher serum HbA1c levels compared to the negative $H$. pylori group (5.78\% vs. $5.69 \%, p=0.007$ ) [70]. Another study in China revealed individuals with $H$. pylori infection had a higher level HbA1C than those who did not [71]. Considering 
the $\mathrm{HbA1c}$ is a valid and reliable indicator for estimating average blood sugar in long-term, it seems to be more valid to evaluate the effect of chronic $H$. pylori infection on blood glucose regulation, because fasting glucose levels are subject to daily changes such as diet and physical activity which these fluctuations may impair any association between $H$. pylori infection and glucose regulation [72-74]. In addition, in subgroup analysis relationship between $H$. pylori and the risk of diabetes was different by age. This finding was consistent with results of other reports, because the different studies have shown that the prevalence of $H$. pylori infection varies with age [75].

Finally, association between $H$. pylori and the risk of diabetes was different by methods for $H$. pylori detection in subgroup analysis. This suggests that this factor could be an important source of heterogeneity in the studies included in the meta-analysis, because different methods of detection for $H$. pylori had different accuracy and precision in such cases the serological tests of anti- $H$. pylori IgG or/and IgA antibody in serum may be reported with different degree of false positives [76, 77]. As a result, association H. pylori and the risk of diabetes may be different according to the method of diagnosis of infection.

\section{Strengths and limitations}

This study similar to other studies has some limitations and strengths.

One of the issue which make distinguish this metaanalysis with the previous ones is dealing with heterogeneity through a subgroups analysis based on type of diabetes, geographical regions, age, and level of HbA1c, duration of diabetes and detection methods of $H$. pylori. Another strength point of our meta-analysis is considering as much as reported and published studies in comparison with other systematic reviews (41 studies) that we were unable to investigate the exact effect of the publication bias.

Also, this study has some limitations. Firstly, missing potential studies e.g. limiting full- text review to English language articles may be lead to some degree of selection bias. Secondly, all studies included in meta-analysis were case-control, hence, the design and implementation of cohort studies are essential for detailed assessment of the association between H. pylori infection and diabetes. Thirdly, personal judgments may be effect on search of articles, data extraction and assessment of included articles in meta-analysis.

\section{Conclusion}

According to this systematic review \& meta-analysis, it can be concluded that $H$. pylori infection could be a potential risk factor for diabetes particularly type 2 diabetes, however further prospective studies are necessary to show the direction of this association.

\section{Abbreviations}

Cl: Confidence Interval; OR: Odds Ratio; IDDM: Insulin-Dependent Diabetes Mellitus; NIDDM: Non-Insulin-Dependent Diabetes Mellitus; CINAHL: Cumulative Index to Nursing and Allied Health Literature; EMBASE: Excerpta Medica dataBASE; STROBE: Strengthening the Reporting of Observationally Studies in Epidemiology; PRISMA: Preferred reporting items for systematic reviews and meta-analyses; H. pylori: Helicobacter Pylori

\section{Acknowledgements}

Not applicable.

\section{Authors' contributions}

YM conceptualized the idea for this review, formulated the review question, and objectives, assisted with the development of the final search strategy, contributed to the data analysis/ interpretation, and writing the manuscript. KM, SN, LS, HM and RR contributed to the conceptualization of the final review question, formulation of the review objectives, data analysis/ interpretation, and writing the manuscript. HM, LS, and ABM contributed to the conducting the searches, data extraction and data analysis/interpretation. All authors read and approved the final manuscript.

\section{Funding}

This research did not receive any specific grant from funding agencies in the public, commercial, or not-for-profit sectors.

\section{Availability of data and materials}

Input data for the analyses are available from the corresponding author on request.

\section{Ethics approval and consent to participate}

Not applicable.

\section{Consent for publication \\ Not applicable.}

\section{Competing interests}

The authors declare that they have no competing interests.

\section{Author details}

${ }^{1}$ Department of Biostatistics and Epidemiology, School of Medicine, Zanjan University of Medical Sciences, Zanjan, Iran. ${ }^{2}$ Department of Epidemiology, School of Public Health, Iran University of Medical Sciences, Tehran, Iran.

${ }^{3}$ Social Determinants of Health Research Center, Research Institute for Health Development, Kurdistan University of Medical Sciences, Sanandaj, Iran.

${ }^{4}$ Research Center of Pediatric Infection Diseases, Institute of Immunology and Infection Diseases, Iran University of Medical Sciences, Tehran, Iran.

${ }^{5}$ Department of Endocrinology, Faculty of Medicine, Kurdistan University of Medical Science, Sanandaj, Iran. ${ }^{6}$ Faculty of Medicine, Kurdistan University of Medical Science, Sanandaj, Iran.

Received: 26 February 2020 Accepted: 17 March 2020

Published online: 24 March 2020

\section{References}

1. Ozen A, Furman A, Berber M, Karatepe HO, Mutlu N, Sarıçoban HE, et al. The effect of helicobacter pylori and economic status on growth parameters and leptin, ghrelin, and insulin-like growth factor (IGF)-I concentrations in children. Helicobacter. 2011;16(1):55-65.

2. Li JZ, Li JY, Wu TF, Xu JH, Huang CZ, Cheng D, Chen QK, Yu T. Helicobacter pylori infection is associated with type 2 diabetes, not type 1 diabetes: an updated meta-analysis. Gastroenterol Res Pract. 2017;2017(1):15.

3. Bajaj S, Rekwal L, Misra S, Misra V, Yadav RK, Srivastava A. Association of helicobacter pylori infection with type 2 diabetes. Indian J Endocrinol Metab. 2014;18(5):694

4. Gulcelik N, Kaya E, Demirbas B, Culha C, Koc G, Ozkaya M, et al. Helicobacter pylori prevalence in diabetic patients and its relationship with dyspepsia and autonomic neuropathy. J Endocrinol Investig. 2005;28(5):214-7.

5. Georges J-L, Rupprecht HJ, Blankenberg S, Poirier O, Bickel C, Hafner G, et al. Impact of pathogen burden in patients with coronary artery disease in relation to systemic inflammation and variation in genes encoding cytokines. Am J Cardiol. 2003;92(5):515-21. 
6. Simanek AM, Dowd JB, Aiello AE. Persistent pathogens linking socioeconomic position and cardiovascular disease in the US. Int J Epidemiol. 2008;38(3):775-87.

7. Wellen KE, Hotamisligil GS. Inflammation, stress, and diabetes. J Clin Invest. 2005;115(5):1111-9.

8. Shaw JE, Sicree RA, Zimmet PZ. Global estimates of the prevalence of diabetes for 2010 and 2030. Diabetes Res Clin Pract. 2010;87(1):4-14.

9. Rathmann W, Giani G. Global prevalence of diabetes: estimates for the year 2000 and projections for 2030: response to Wild et al. Diabetes Care. 2004 27(10):2568-9.

10. Wild S, Roglic G, Green A, Sicree R, King H. Global prevalence of diabetes: estimates for the year 2000 and projections for 2030. Diabetes Care. 2004; 27(5):1047-53.

11. Simon L, Tornóczky J, Toth M, Jámbor M, Sudár Z. The significance of campylobacter pylori infection in gastroenterologic and diabetic practice. Orv Hetil. 1989;130(25):1325-9.

12. Oldenburg B, Diepersloot R, Hoekstra J. High seroprevalence ofHelicobacter pylori in diabetes mellitus patients. Dig Dis Sci. 1996;41(3):458-61.

13. Papamichael KX, Papaioannou G, Karga H, Roussos A, Mantzaris GJ. Helicobacter pylori infection and endocrine disorders: is there a link? World J Gastroenterol: WJG. 2009:15(22):2701.

14. Kayar Y, Pamukçu Ö, Eroğlu H, Kalkan Erol K, Ilhan A, Kocaman O. Relationship between helicobacter pylori infections in diabetic patients and inflammations, metabolic syndrome, and complications. Int J Chronic dis. 2015;2015(1):6.

15. Devrajani BR, Shah SZA, Soomro AA, Devrajani T. Type 2 diabetes mellitus: a risk factor for helicobacter pylori infection: a hospital based case-control study. Int J Diab Dev Countries. 2010;30(1):22.

16. Anastasios R, Goritsas C, Papamihail C, Trigidou R, Garzonis P, Ferti A. Helicobacter pylori infection in diabetic patients: prevalence and endoscopic findings. Eur J Intern Med. 2002;13(6):376-9.

17. Zhou F, Zhong X, Chen J, Li C, Shang M, Jiang C, et al. Helicobacter pylori infection associated with type 2 diabetic nephropathy in patients with dyspeptic symptoms. Diabetes Res Clin Pract. 2015;110(3):328-34.

18. Knottnerus A, Tugwell P. STROBE - a checklist to strengthen the reporting of observational studies in epidemiology. J Clin Eng. 2008;61(4):323.

19. Stroup DF, Berlin JA, Morton SC, Olkin I, Williamson GD, Rennie D, et al. Meta-analysis of observational studies in epidemiology: a proposal for reporting. Jama. 2000;283(15):2008-12.

20. Moher D, Liberati A, Tetzlaff J, Altman DG. Preferred reporting items for systematic reviews and meta-analyses: the PRISMA statement. Ann Intern Med. 2009;151(4):264-9.

21. Margulis AV, Pladevall M, Riera-Guardia N, Varas-Lorenzo C, Hazell L, Berkman ND, et al. Quality assessment of observational studies in a drugsafety systematic review, comparison of two tools: the Newcastle-Ottawa scale and the RTI item bank. Clin Epidemiol. 2014;6:359.

22. DerSimonian R, Laird N. Meta-analysis in clinical trials. Control Clin Trials. 1986:7(3):177-88.

23. Higgins J, Thompson SG. Quantifying heterogeneity in a meta-analysis. Stat Med. 2002;21(11):1539-58.

24. Egger M, Smith GD, Minder C. Bias in meta-analysis detected by a simple, graphical test. Br Med J. 1998;316(7129):470-1.

25. Egger $M$, Smith GD, Schneider M, Minder C. Bias in meta-analysis detected by a simple, graphical test. Bmj. 1997;315(7109):629-34.

26. Małecki M, Bień A, Galicka-Latała D, Stachura J, Sieradzki J. The prevalence of helicobacter pylori infection and types of gastritis in diabetic patients. The Krakow study. Exp Clin Endocrinol Diabetes. 1996;104(05):365-9.

27. Pocecco M, Buratti E, Tommasini A, Torre G, Not T. High risk of Helicobacter pylori infection associated with cow's milk antibodies in young diabetics. Acta paediatrica (Oslo, Norway : 1992). 1997;86(7):700-3.

28. Gentile S, Turco S, Oliviero B, Torella R. The role of autonomic neuropathy as a risk factor of helicobacter pylori infection in dyspeptic patients with type 2 diabetes mellitus. Diabetes Res Clin Pract. 1998;42(1):41-8.

29. De Luis D, De La Calle H, Roy G, De Argila CM, Valdezate S, Canton R, et al Helicobacter pylori infection and insulin-dependent diabetes mellitus. Diabetes Res Clin Pract. 1998;39(2):143-6.

30. Gasbarrini A, Ojetti V, Pitocco D, De Luca A, Franceschi F, Candelli M, et al. Helicobacter pylori infection in patients affected by insulin-dependent diabetes mellitus. Eur J Gastroenterol Hepatol. 1998;10(6):469-72.

31. Salardi S, Cacciari E, Menegatti M, Landi F, Mazzanti L, Stella FA, et al. Helicobacter pylori and type 1 diabetes mellitus in children. J Pediatr Gastroenterol Nutr. 1999;28(3):307-9.
32. Arslan D, Kendirci M, Kurtoglu S, Kula M. Helicobacter pylori infection in children with insulin dependent diabetes mellitus. J Pediatr Endocrinol Metab. 2000;13(5):553-6.

33. Dore MP, Bilotta M, Malaty HM, Pacifico A, Maioli M, Graham DY, et al. Diabetes mellitus and helicobacter pylori infection. Nutrition. 2000;16(6): 407-10.

34. Senturk O, Canturk Z, Cetinarslan B, Ercin C, Hulagu S, Canturk NZ. Prevalence and comparisons of five different diagnostic methods for helicobacter pylori in diabetic patients. Endocr Res. 2001;27(1-2):179-89.

35. Ravera M, Bahenda S, Owor R, Visona R. Helicobacter pylori infection in diabetic patients with dyspepsia in Uganda. Dig Liver Dis. 2001;33(4):390-1.

36. Ko GT, Chan FK, Chan WB, Sung JJ, Tsoi CL, To KF, et al. Helicobacter pylori infection in Chinese subjects with type 2 diabetes. Endocr Res. 2001;27(1-2):171-7.

37. M. M, G. L, D. M, E. S, R. I, P. S, et al. Increased prevalence of helicobacter pyhri in patients with diabetes mellitus. Dig Liver Dis. 2001;33(1):21-9.

38. Quatrini M, Boarino V, Ghidoni A, Baldassarri AR, Bianchi PA, Bardella MT. Helicobacter pylori prevalence in patients with diabetes and its relationship to dyspeptic symptoms. J Clin Gastroenterol. 2001;32(3):215-7.

39. Cenerelli S, Bonazzi P, Galeazzi R, Testa I, Bonfigli AR, Sirolla C, et al. Helicobacter pylori masks differences in homocysteine plasma levels between controls and type 2 diabetic patients. Eur J Clin Investig. 2002; 32(3):158-62.

40. Maule S, Lombardo L, Rossi C, Crocella L, Masoero G, Della Monica P, et al. Helicobacter pylori infection and gastric function in primary autonomic neuropathy. Clin Auton Res. 2002;12(3):193-6.

41. Candelli M, Rigante D, Marietti G, Nista EC, Crea F, Bartolozzi F, et al. Helicobacter pylori, gastrointestinal symptoms, and metabolic control in young type 1 diabetes mellitus patients. Pediatrics. 2003;111(4):800-3.

42. Jaber SM. Helicobacter pylori seropositivity in children with chronic disease in Jeddah, Saudi Arabia. Saudi J Gastroenterol. 2006;12(1):21-6.

43. Bener A, Micallef R, Afifi M, Derbala M, Al-Mulla HM, Usmani MA. Association between type 2 diabetes mellitus and helicobacter pylori infection. Turk J Gastroenterol. 2007;18(4):225-9.

44. Demir M, Gokturk HS, Ozturk NA, Kulaksizoglu M, Serin E, Yilmaz U. Helicobacter pylori prevalence in diabetes mellitus patients with dyspeptic symptoms and its relationship to glycemic control and late complications. Dig Dis Sci. 2008;53(10):2646-9.

45. Ariizumi K, Koike $T$, Ohara $S$, Inomata $Y$, Abe $Y$, lijima $K$, et al. Incidence of reflux esophagitis and $\mathrm{H}$ pylori infection in diabetic patients. World J Gastroenterol. 2008;14(20):3212-7.

46. Hamed SA, Amine NF, Galal GM, Helal SR, Tag El-Din LM, Shawky OA, et al. Vascular risks and complications in diabetes mellitus: the role of helicobacter pylori infection. J Stroke Cerebrovasc Dis. 2008;17(2):86-94.

47. Cabral VLR, Patrício FRDS, Gabbay MAL, Dib SA, Miszputen SJ. Intraepithelial lymphocytes in duodenum from Brazilian adolescents with type 1 diabetes. Influence of Helicobacter pylori. Pediatr Diabetes. 2009;10(5):316-20.

48. Lazaraki G, Kountouras J, Metallidis S, Vrettou E, Alevizos M, Tzioufa V, et al. Endothelial nitric oxide synthase (eNOS) is not upregulated in gastric mucosa of helicobacter pylori (H. pylori)-positive patients with type 2 diabetes mellitus. Dig Liver Dis. 2009;41(4):253-62.

49. Krause I, Anaya JM, Fraser A, Barzilai O, Ram M, Abad V, et al. Anti-infectious antibodies and autoimmune-associated autoantibodies in patients with type I diabetes mellitus and their close family members. Ann N Y Acad Sci. 2009;1173:633-9.

50. Ibrahim A, Zaher T, Ghonemy TA, El-Azim SA, El-Azim MA, Ramadan A. Impact of cytotoxin-associated gene a of helicobacter pylori strains on microalbuminuria in type 2 diabetes. Saudi J kidney Dis Transpl. 2010;21(4):694-700.

51. El-Eshmawy MM, El-Hawary AK, Abdel Gawad SS, El-Baiomy AA. Helicobacter pylori infection might be responsible for the interconnection between type 1 diabetes and autoimmune thyroiditis. Diabetol Metab Syndr. 2011;3(1):28.

52. De Block CEM, De Leeuw IH, Bogers J, Pelckmans PA, leven MM, Van Marck EAE, et al. Helicobacter pylori, parietal cell antibodies and autoimmune gastropathy in type 1 diabetes mellitus. Aliment Pharmacol Ther. 2002;16(2): 281-9.

53. Candelli M, Rigante D, Schiavino A, Gabrielli M, Crea F, Del Lungo LM, et al. High reinfection rate of Helicobacter pylori in young type 1 diabetic patients: a three-year follow-up study. Age (years). 2012;19(4.3):19.8-4.3.

54. Jafarzadeh A, Rezayati MT, Nemati M. Helicobacter pylori seropositivity in patients with type 2 diabetes mellitus in south-east of Iran. Acta medica Iranica. 2013;51(12):892-6. 
55. Keramat F, Hashemi SH, Majlesi A, Haddadinejad S, Esfehani AM, Poorolaja $J$. The association between diabetes mellitus and helicobacter pylori infection. Int J Diabetes Dev Countries. 2013;33(3):155-60.

56. Zekry OA, Abd Elwahid HA. The association between helicobacter pylori infection, type 1 diabetes mellitus, and autoimmune thyroiditis. J Egyptian Public Health Assoc. 2013;88(3):143-7.

57. Chobot A, Bak-Drabik K, Skala-Zamorowska E, Krzywicka A, Kwiecien J, Polanska J. Helicobacter pylori infection in type 1 diabetes children and adolescents using 13C urea breath test. Pol J Microbiol. 2014;63(1):63-7.

58. Fayed SB. Abd El Dayem SM, Khalil E, Abd El Kader M, Abd El Halim E. helicobacter pylori infection in children with type 1 diabetes mellitus. Macedonian J Med Sci. 2014;7(1):114-8.

59. Bazmamoun H, Rafeey M, Nikpouri M, Ghergherehchi R. Helicobacter pylori infection in children with type 1 diabetes mellitus: a case-control study. J Res Health Sci. 2016:16(2):68-71.

60. Osman SM, Mubarak SM, Omer IM, Abdullah MA. Helicobacter pylori infection and the onset of type 1 diabetes mellitus in Sudanese children. Sudanese J paediatr. 2016;16(2):59-66.

61. Alzahrani S, Nelson J, Moss SF, Paulus JK, Knowler WC, Pittas AG. H. Pylori seroprevalence and risk of diabetes: an ancillary case-control study nested in the diabetes prevention program. J Diabetes Complicat. 2017;31(10):1515-20

62. Vaishnav B, Shaikh S, Bamanikar A, Kakrani A, Tambile R. Diagnostic upper gastrointestinal endoscopy and prevalence of $<i>$ helicobacter pylori</i> infection in dyspeptic type 2 diabetes mellitus patients. J Dig Endoscopy. 2018;9(2):53-60

63. Wang F, Liu J, Lv Z. Association of Helicobacter pylori infection with diabetes mellitus and diabetic nephropathy: a meta-analysis of 39 studies involving more than 20,000 participants. Scand J Infect Dis. 2013;45(12):930-8.

64. Zhou X, Zhang C, Wu J, Zhang G. Association between helicobacter pylori infection and diabetes mellitus: a meta-analysis of observational studies. Diabetes Res Clin Pract. 2013;99(2):200-8.

65. Woodward M, Morrison C, McColl K. An investigation into factors associated with helicobacter pylori infection. J Clin Epidemiol. 2000;53(2):175-81.

66. Pradhan AD, Manson JE, Rifai N, Buring JE, Ridker PM. C-reactive protein, interleukin 6, and risk of developing type 2 diabetes mellitus. Jama. 2001; 286(3):327-34

67. Manco M, Putignani L, Bottazzo GF. Gut microbiota, lipopolysaccharides, and innate immunity in the pathogenesis of obesity and cardiovascular risk. Endocr Rev. 2010;31(6):817-44.

68. Crabtree J, Shallcross T, Heatley R, Wyatt J. Mucosal tumour necrosis factor alpha and interleukin-6 in patients with helicobacter pylori associated gastritis. Gut. 1991;32(12):1473-7.

69. Yang YJ, Wu CT, Ou HY, Lin CH, Cheng HC, Chang WL, Chen WY, Yang HB, Lu CC, Sheu BS. Male non-insulin users with type 2 diabetes mellitus are predisposed to gastric corpus-predominant inflammation after H. pylori infection. J Biomed Sci. 2017;24(1):82.

70. Hsieh MC, Wang SS, Hsieh YT, Kuo FC, Soon MS, Wu DC. H elicobacter pylori infection associated with high $\mathrm{H}$ b a $1 \mathrm{c}$ and type 2 diabetes. Eur J Clin Investig. 2013;43(9):949-56

71. Han X, Li Y, Wang J, Liu B, Hu H, Li X, et al. Helicobacter pylori infection is associated with type 2 diabetes among a middle-and old-age Chinese population. Diabetes Metab Res Rev. 2016;32(1):95-101.

72. Chen Y, Blaser MJ. Association between gastric helicobacter pylori colonization and glycated hemoglobin levels. J Infect Dis. 2012;205(8):1195-202.

73. Buell C, Kermah D, Davidson MB. Utility of A1C for diabetes screening in the 1999-2004 NHANES population. Diabetes Care. 2007;30(9):2233-5.

74. Rohlfing C, Little R, Wiedmeyer H, England J, Goldstein D. Use of GHb ( $\mathrm{HbA}$ (1c)) to screen for undiagnosed diabetes in the US population-Response. Diabetes Care. 2000;23(8):1208.

75. Eshraghian A, Hashemi SA, Jahromi AH, Eshraghian H, Masoompour SM, Davarpanah MA, et al. Helicobacter pylori infection as a risk factor for insulin resistance. Dig Dis Sci. 2009;54(9):1966-70.

76. Miftahussurur M, Yamaoka Y. Diagnostic methods of helicobacter pylori infection for epidemiological studies: critical importance of indirect test validation. Biomed Res Int. 2016;2016(1):14.

77. Tonkic A, Vukovic J, Cindro PV, Pisac VP, Tonkic M. Diagnosis of helicobacter pylori infection. Wien Klin Wochenschr. 2018;130(17-18):530-4.

\section{Publisher's Note}

Springer Nature remains neutral with regard to jurisdictional claims in published maps and institutional affiliations.

\section{Ready to submit your research? Choose BMC and benefit from:}

- fast, convenient online submission

- thorough peer review by experienced researchers in your field

- rapid publication on acceptance

- support for research data, including large and complex data types

- gold Open Access which fosters wider collaboration and increased citations

- maximum visibility for your research: over $100 \mathrm{M}$ website views per year

At BMC, research is always in progress.

Learn more biomedcentral.com/submissions 